57. アピカルーインプラントに関する奏験的研究

58. 歯槽骨形成に関する実験的研究 (其の一) Kiel Bone graft移植実験 (第二報)

は明瞭に見えるが， 3 週目，4 週目になる己周囲骨壁 から骨梁の新生が見られ辺縁は次第に不明瞭になって いる.

\section{組 織 所 見}

先ず根切面部を見ると，全例を通じて根切面と人工 歯根端の間に軟組織の進入があり，尖症像が認められ る. 又根切面象牙質，七メント質の吸収が見られる。

側面部と底面部では，術后 1 週間目にはバイタリウ ムに接した組織にかなり強い細胞浸潤が見られるが， 底面部に於ては細胞浸潤のない所も存在している。

術后 2 週間目では，側面部から底面部にかけて全面 に於て，1週目よりは細胞浸潤は消退して括り，周囲 の骨壁から僅かに骨染の新理像が認められる。

術后 3 週目の例では，周囲骨壁からの新生骨梁の添 加は，2 週目より進んで居るがバイタリウムに接する 組織には，やや強い細胞漫潤を認める。

術后 4 週目になると, バイタリウムの周团の尖症像 は，1，2週目に比べてかなり消退して線維成分が密 となり，バイタリウムに沼ってほぼ平行に，規則的に 排列して居る.

又その周囲の新生骨染の出現も進みやや太さを増し ている。

総 括, 考 按

以上の所見から，今回の赛験を考察すると，先ず第 1 亿全例を通じて根切面と，バイタリゥム人工歯根端 の間に軟組織の進入が認められた。

実際的には，人工歯根端上面之根切面が緊密に接合 していて,この部に於ける軟組織の進入が無い事が望 まれるわけであるのでこの点については，今後更に検 討を要する必要があるところと思っている.
次にバイタリウムに接する周囲組織の反応について は，1週目にはかなり強い反応性尖症像が見られるが これはバイタリウムの直接の影響というよりも,この 時期までは手術による侵襲が相当に影響しているもの と思われる。

これが 4 週目になると尖症像は，1，2週目に比し て少なくなり，線維性結合組織によってバイタリウム を包んでいる状態が観察された。

これらの所見から，バイタリウムは周囲組織に対し て，為害作用の少ない金属であるように思われるので 今回の実験から考えてみるに, 根切面とバイタリウム 上面との接合を完全に行ない得れば，根端切除後に於 ける，アピカルインプラントとしてバイタリウムの使 用が可能となり得るのではないかと思われる.

\section{参 考 文 献}

Bermier, J. and Canby, C. ; Histologic studies on the reaction of alueolar bone to Vitallium Implants : J. A. D. A., 30, 183, (1943) .

Seidenberg, M. ; alloplastic intraosseous Implants as Precursors to indiuidual tooth replacements : J. Pros. Dent. , 13, 963, (1963) .

Patrick D. Toto, NicholasC. Choukas, and Anthony abati; Reaction of bone to magnetic Implant : J. D. Res., 42 ( 2), 643, (1963) .

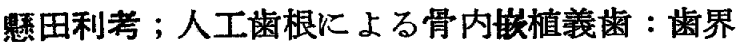
展望, 27 (6)， (1966).

\title{
58. 歯槽骨形成に関する実験的研究
}

\section{（其の一）Kiel Bone graft移植実験（第二報）}

Experimental Studies on the Plastic of Alveolar Bone

[1] Experimental Transplantation of Kiel Bone Graft (The 2 nd Report)

\section{九州歯科大学口腔外科学教室 (指導 : 平川正輝教授) \\ 九州歯科大学口腔病理学教室（指導：上野正康教授）}

$$
\text { 坪 根 重治 }
$$

\section{緒訔}

歯槽骨は抜歯後徐々に吸収されるため, 同部の歯槽 堤の形態もしだいに縮小低下をきたす。このことは，
一般に歯牙喪失期間の長い程著明となり，その久損部 が大きい程，義歯補綴の上で種々の障碍をきたすこと がある。この様な場合，吸収された歯槽骨を形成して 
有床義歯の作製及び維持に好ましい形態を与えるため の一つの試みとして，村田等の「歯槽頂部えの自家 骨, 軟骨移植に関する実験的研究」があるが，これを 臨床的に応用するには, 移植骨の種類, あるいは移植 方法, その他多くの研究課題が残されている.

そこで私は，歯槽堤の改善を計る目的て臨床的に屡 々使用されている脱蛋白骨 Kiel Bone graft（以下K B と略す）を移植骨として歯槽形成の動物実験を行い あわせて自家肋骨 (以下ABと略す) を移植骨として も数例の実験を行ったので，その成績を報告する.

\section{実 験 方 法}

生後 1 年から 2 年くらいの中型成犬を使用して，そ の下顎小歯部を歯槽骨と共に抜去し，抜歯後 1 ケ月 を経過した歯槽頂に骨のみで溝状の窝洞を形成しそ の窝洞に適合する様に形成した海綿骨質から成る K B ならびに自家肋骨を，其の上端が歯槽頂より高くなる ような状態に嵌入移植した。な和，別に同じく抜齿後 1 ケ月を経過した歯槽頂に，骨移植の場合と同樣の溝 状の窝洞を形成しただけのるのを対照例として，それ ぞれの実験グループについての経日的変化を病理組織 学的に検索した。実験期間は，KB移植例では 1 週，

2 週，3週，1 ケ月，2ケ月拈よび 3 ケ月， A B 移植 例では 1 週，2週，1ケ月拈び２ケ月である。また 対照は 3 週，1 月月，2 月月扎よび 3 ケ月のものにつ いて観察した。

術後 1 週目:

\section{実 験 成 績}

K B移植例においては，盆底および梁部の窩壁から 骨稜の新生がみられるが，K Bからの骨新生はみられ ない. K B の骨質の間は深部に少量の幼若肉芽組織が 介在するが，大部分は血餅によってみたされている．

A B 移植例では，窩底や梁部の窩壁からの新生骨稜 の添加はK B の場合と同様であるが，更に移植骨の方 からも骨の新生が始っており, それらの新生骨梁によ って，母骨と移植骨が結合している.

術後 2 週目:

K B移植例では，窩底や窝壁からの新生骨梁の添加 が進み，K B骨質の間を縫って新生している.しかし ながら，K B の骨貿の周囲に吸収細胞が出現している 所見もみられる.

A B移植例では，窝底や窝壁，また移植骨でも母骨 に近接した部からの骨稜の添加が進み，母骨と移植骨 は完全に結合している. しかし，一方では移植骨の頂 縁部に骨吸収像がみられる。
対照例においては，新生骨稜が窝洞の約 $1 / 3$ 程度迄新 生している.

術後 3 週目：

K B 移植例では, 窝底および窝壁からの骨稜の新生 は更に進み，裔洞上縁にも新生骨梁の添加が起ってい る.K Bが，それらの骨梁中に埋められて行く所見が

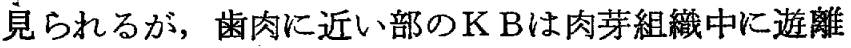
していて，その周囲には吸収が起っている。

術後 1 ケ月目：

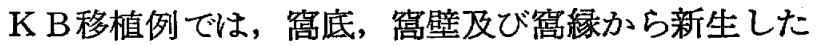
骨梁が，KBを埋入しつ〉更に増殖しているが，K B の上層部，すなわち歯槽頂部に相当する部位では未だ 新生骨梁の形成はみられず，K Bが遊離して和り更に その周囲には可成り多くの吸収細胞が出現している.

A B 移植例では, 窝底, 䔰壁とも新生骨の添加によ り，母骨と移植骨が完全に結合している．移植骨の骨 髄腔内は，全体的に血管の豊富な若い肉芽組織によっ て占められているが，上方に較べると下方の窝底に近 うくに従って線維成分が多く，僅少の骨染の添加がみ られる，歯槽頂より高くした部の移植骨周縁には，吸 収細胞が並んでいる。

対照例では，窝底拉よび窝壁からの骨梁の新生が進

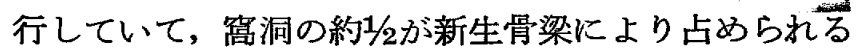
ようになっている.

術後 2 ケ月目:

K B 移植例では，移植したK B は新生骨中に包含さ れているものと，また表層部には遊離して存在するす のとがある，このK Bは，量的には移植時よりかなり 少なくなっており，表層部に遊離した $\mathrm{KB}$ ○周团は吸 収細胞により吸収されている，新生骨梁の形成は，未 だ元の歯槽堤の高さに迄回復していない.

A B 移植例では，窩底，窩壁とも母骨と移植骨之の 区別がつきにくい，移植骨の骨䯣中では，新生骨の添 加, 改造が行われ, 正常な骨髄やハーヴォ一氏管もみ られる，窝縁より高くしておいた部分の移植骨は，ほ とんど吸収され消失していて，その表面には吸収細胞 が並んでいる。

対照例では，この時期になると，营洞は表面の中央 部の一部を残して大部分は新生骨により満たされてお り，新生骨内には正常な骨䯣やハーヴォー氏管がみら れる。しかし，表層部には未だ緻密骨の層板構造はみ られず，辺縁に造骨細胞が並んでいて更に骨の添加を 続けているところむ多い.

術後 3 ケ月目： 
58. 歯槽骨形成に関する実験的研究（其の一） Kiel Bone graft移殖実験（第二報）

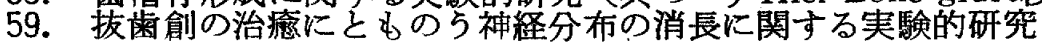

K B 移植例では，窝洞内は新生骨により満たされて いて，その中に少量のK Bが包埋されている．2ゲ月 目に見られた新生骨縁上に島状に遊離していたK Bは 全く吸収消失してしまっている．新生骨の改造は進ん でいて，骨葡やハーヴィー氏管もみられ，ハーヴォー 氏管周囲の層板構造も明らかである．新生骨の高さは ほ心゙もとの高さ迄回復しており，表面には造骨細胞が 並んでいる.

対照例では, 窝洞内の骨の添加が進み, 表面はほぼ もとの高さまで回復し, 僅かに層板構造が認められ， 造骨細胞は見られなかった。

\section{総括}

K B 移植例においては，移植後 1 週目には窝底およ び墧壁からの骨梁の新生が行われて㧍り，それらはK B の骨質の間を縫って漸次新生して行くが，K B 自体 からの骨梁の新生は認められなかった。この骨梁の形 成は経日的に増加して, 移植したK B は漸次骨梁中に 埋められて行くが，上方部のいわゆる歯肉に近い所の K B は，島状に新生骨縁上に取り残されて，新生骨梁 によって包含される前に吸収消失してしまう。そのた め, 移植後 3 ケ月目には, 窝洞内の $\mathrm{K} \mathrm{B}$ は新生骨梁に よって完全に包み込まれてしまうにもかわわらず，䆝 緑より高い位置に在ったK Bは消失してしまい, 結果 としては，歯槽頂の高さは窩洞の中央部では移植前の 高さ迄も回復しておらず, 若干凹んだ状態に在り，僅 かに简䋑部における少量の骨梁の添加がみられる程度
である.

一方 A B移植例では，これまでに得た実験結果をみ ると，K Bの場合にはみられなかった移植骨自体から の骨梁の新生が明らかに認められ，そのため 1 週目か ら2 週目にかけて，母骨から出た新生骨梁と移植骨か らの新生骨梁の結合によって移植骨は窝洞内に強く固 定されていて，この時期には歯槽頂の高さは高くなっ た状態にある。しかし，1週目からすで窝洞外に高 く形成した移植骨の表面には，吸収細胞が現われて骨 の吸収が始っており，この骨の吸収は漸次進行して移 植後 2 ケ月目には，窝縁より高い部分の移植骨はかな り吸収されてしまっている。

なお，このA B移植実験は，実験例数も少なく現在 な技実験を行っており，はっきりした結果の判定は次 回にゆづりたいと思う。

\section{参 考 文 献}

1) 村田睦男; 抜齿後歯槽骨の变化に関する補綴学 的研究：日本口腔科学会雑誌，14，204，(1965）

2) 塩田 覚他; 歯槽堤えの自家骨軟骨移植に関す る実験的研究 : 京大口腔科学紀要, 5,37, (1965)

3 ) 山本吉蔵; Kiel Bone graft の蛋白残存性 : 災 害医学, 8，605，（1965）.

4) 三森甲子夫; 脱灰骨移植の実験的研究 : 移植, 1, 204, (1966).

5）飯田博美；歯槽骨に対する骨移植の実験的研究 : 医学研究，29，2823，（1959）.

\section{9. 抜茵創の治瘾にとものう神経分布の消長に 関する実験的研究}

Experimental Study of the Change of Nerve Distribution on the Healing Process of Tooth Extraction Wounds in Dog

九州齿科大学口腔病理学教室 (指導 : 上野正康教授)

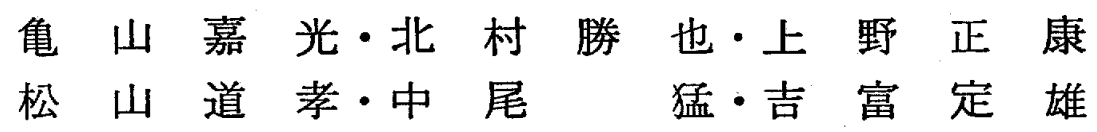

粕

\section{言}

抜歯創の治瘾機転に関する研究は，古くから多くの 人ふにより，種々なる方法で行なわれている。なかで も，正常な抜歯創の治瘺過程についての組織学的研究 とX線学的研究は多く, 最近では, 各種の造影剂を使 用しての抜崡創の血管分布の消長に関する研究む多く
見らけられる。しかしながらこれら多数の拔歯創の 研究に颃いて，神経分布の消長に関する研究は，皆無 と言っても過言ではない，私達は，この抜歯創の神経 分布の消長に関する研究を行いつつあり，現在までの 所見を報告する。 